\title{
The Effect Of Food Safety Accidents On The Perception Of Risk Among Taiwanese Vocational School Students Majoring In Tourism
}

\author{
Kuang-Yu, Shih ${ }^{a}$, Tuan-Liang Hong ${ }^{b}$, S.Y. Leec ${ }^{c}$ Ta-Yu, Lind \\ ${ }^{a}$ Deparment of Tourism Management, National Kaohsiung University of Science and Technology \\ (TAIWAN), ${ }^{\mathrm{b}}$ Departent of Culinary Arts Management, I-Shou University (TAIWAN), ${ }^{\mathrm{c}}$ Department \\ of Food and Beverage Management, University of Kang Ning (TAIWAN), ${ }^{\mathrm{d}}$ Department of Leisure \\ Management, University of Kang Ning (TAIWAN)
}

\begin{abstract}
In this study we analyze the degree of awareness of food safety risk among tourism students. Questionnaires were distributed to 148 students randomly selected from tourism majors in vocational schools in Tainan, Taiwan. A total of 30 questions over the topics on the sanitation, washroom sanitation, food sanitation, staff sanitation and table ware cleanliness were graded on a scale of 5 according to the perceived importance of the topic The survey reveals that of the five sanitation items, food sanitation received the highest score while the washroom sanitation the lowest.
\end{abstract}

Keywords: food Safety,Students, Tourism

\section{Introduction}

Media coverage of a series of recent food safety accidents has not only distorted public perception of food safety and confidence (Grunert, 2002; Lobb, 2004). It has further adversely affected Taiwan tourism industry ( $\mathrm{Wu}, 2015)$. Strengthening of overall food safety and stemming the erosion of the public perception is clearly an important key to the health of tourism industry.

To the international visitors, tour guides are usually the tourists, first contacts, and as such they are vital in the visitors, understanding of Taiwan and their overall impression of the experience. A guide with adequate knowledge of food safety helps to assist and advise the visitors. Since the tourism students of the vocational schools are the major source of guides, 
it is therefore vital for the development of the tourism industry that the students be sufficiently trained in the knowledge of food safety

Existing literatures on food safety dealt with consumers, perception (Yeung and Morris,2001), knowledge and attitude (Lin and sneed,2005), students, understanding of food preparation (Haapala and Probart,2004).Or evaluation (Lammerding and Fazil,2000).Few dealt with the perception of the vocational tourism students.

\section{Methodology}

\subsection{Data a collection and sample}

Two vocational schools in the city of Tainan were randomly selected and from each selected school two class was then chosen to receive 100 questionnaires. A total of 200 questionnaires yielded 148 usable returns. The valid recovery rate is $72.0 \%$.

\subsection{Questionnaire}

The questionnaires of food safety risk perception were used to research tool. A total of 30 questions over the topics on the cleanliness of surroundings, washroom cleanliness, food sanitation, personnel hygiene practice, and tableware cleanliness were graded on a scale of 5 according to the perceived importance of the topic (Perlik 2002). Further factor analysis data showed that KMO (Kaiser-Meyer-Olkin) is higher than 0.5 and Bartlett spherical test is significant level. The eigenvalues are higher than 1.0, and factor loading over 0.4 were classified by principal component analysis.

\subsection{Data analysis}

The SPSS (version 22.0) was used for data analysis. The Cronbach's $\alpha$ and factor analysis were conduct the reliability and validity test for food safety risk scaling. The mean and standard deviation was to realize the situation of food sanitation and safety risk cognition from tourism majors in vocational schools in Tainan, Taiwan. 


\section{Results and Discussion}

\subsection{Sample background}

The descriptive analysis of sample background was showed in table 1 . The female population $(66.9 \%)$ is higher than male $(33.1 \%)$, and the grade $2(38.5 \%)$ is the highest than the grade $3(38.5 \%)$ and grade $1(12.8 \%)$. The students eat out 3.09 times per week and spend 134.7 NT\$ per meal on the average. The acceptable food price was average 174.6 NT\$. The data showed the students eat out acceptable food price was higher than in fact average paying.

Table1 Percentage of sample background $(n=148)$

\begin{tabular}{|llcc|}
\hline Variables & & $n$ & $\%$ \\
\hline Gender & male & 49 & 33.1 \\
& female & 99 & 66.9 \\
& total & 148 & 100.0 \\
Grade & first grader & 19 & 12.8 \\
& second grader & 72 & 48.7 \\
& third grader & 57 & 38.5 \\
& total & 148 & 100.00 \\
\hline
\end{tabular}

\subsection{Eating behavior of students from tourism majors in vocational schools}

The percentage of eating behavior of students from vocational schools were showed in table 2. For eating in restaurant, eating with companion ( 74 persons, $50 \%$ ) is the highest, eating alone is the lowest $(8.1 \%)$. The purpose of eating in restaurant, the only dinning is the highest $(64.2 \%)$, increasing the relation with friends or parents $(7.4 \%)$. The data reveal the purpose of eat in restaurant of students was only dinning and with companies, not for enjoying cuisine and enhance relationship with friends and relatives. 
The Effect Of Food Safety Accidents On The Perception Of Risk Among Taiwanese Vocational School Students Majoring In Tourism

Table2 Percentage of eating behavior for students $(n=148)$

\begin{tabular}{|c|c|c|c|c|}
\hline variable & item & $\mathrm{n}$ & $\%$ & ranking \\
\hline \multirow{4}{*}{$\begin{array}{l}\text { Dining restaurant } \\
\text { usually }\end{array}$} & With companion & 74 & 50.0 & 1 \\
\hline & Indeterminate & 62 & 41.9 & 2 \\
\hline & Dinning along & 12 & 8.1 & 3 \\
\hline & Total & & & \\
\hline \multirow{5}{*}{$\begin{array}{l}\text { Major purpose of } \\
\text { dinning in restaurant }\end{array}$} & Only dinning & 95 & 64.2 & 1 \\
\hline & Invitation by friend & 24 & 16.2 & 2 \\
\hline & Enjoy cuisine & 18 & 12.2 & 3 \\
\hline & $\begin{array}{l}\text { Increasing relationship } \\
\text { with friends and relatives }\end{array}$ & 11 & 7.4 & 4 \\
\hline & Total & 148 & 100.0 & \\
\hline
\end{tabular}

\subsection{The factors on dinning in restaurant of students from tourism majors in vocational schools}

The table 3 showed the highest attractive restaurant ranking are meal type (23\%), the location convenience and habit are $18.9 \%$, sanitation is $12.2 \%$, and the service is $6.8 \%$, respectively. Factors on lowest attractive restaurant of students are environmental dirty (27\%), bad service attitude (20.2\%), meal expensive (16.1\%). The results meaning the meal type, location convenience and habit are major factor for students from vocational schools. Unexpected, the good foodservice and sanitation are the dislike in students. But the students don't like to go to meal in restaurant is bad foodservice. Cenfetelli (2004) mention these inhibiting and enabling perceptions are independent of one another and can coexist. Thus, restaurant with bad foodservice attitude and environment dirty were refused by students, inhibitors factor effect higher than enablers factor of good service and sanitation. 
Table 3 Frequency of factors affecting the choice

\begin{tabular}{|c|c|c|c|c|}
\hline Variables & item & $\mathrm{n}$ & $\%$ & ranking \\
\hline \multirow{8}{*}{$\begin{array}{ll}\text { Major factor of } \\
\text { dinning in restaurant }\end{array}$} & Meal type & 34 & 23.0 & 1 \\
\hline & $\begin{array}{l}\text { Location } \\
\text { convenience }\end{array}$ & 28 & 18.9 & 2 \\
\hline & Habit & 28 & 18.9 & 2 \\
\hline & Hygiene & 18 & 12.2 & 3 \\
\hline & Price & 16 & 10.8 & 4 \\
\hline & Speed of service & 14 & 9.4 & 5 \\
\hline & Service & 10 & 6.8 & 6 \\
\hline & Total & 148 & 100 & \\
\hline \multirow[t]{13}{*}{$\begin{array}{l}\text { Dislike factor for } \\
\text { dinning in restaurant }\end{array}$} & $\begin{array}{l}\text { Environment } \\
\text { dirty }\end{array}$ & 40 & 27.0 & 1 \\
\hline & Bad attitude & 30 & 20.2 & 2 \\
\hline & Expansive & 24 & 16.1 & 3 \\
\hline & Poor taste & 20 & 13.5 & 4 \\
\hline & Poor food quality & 13 & 8.8 & 5 \\
\hline & $\begin{array}{l}\text { See the disease } \\
\text { vector }\end{array}$ & 9 & 6.1 & 7 \\
\hline & Dislike meal type & 6 & 4.1 & 6 \\
\hline & No air condition & 2 & 1.4 & 8 \\
\hline & Location & 2 & 1.4 & 8 \\
\hline & Inconvenience & & & \\
\hline & $\begin{array}{l}\text { Foodservice } \\
\text { slowly }\end{array}$ & 1 & 0.7 & 9 \\
\hline & Failure incorrect & 1 & 0.7 & 9 \\
\hline & Total & 148 & 100.0 & \\
\hline
\end{tabular}




\subsection{The situation of food safety perception of student's tourism major from vocational school}

The students with tourism major from vocational school effect on food safety risk perception, every perspective are higher than 4.2. This data showed the students has high perception in food sanitation and safety risk. The score of food sanitation is 4.41, cleanliness of surroundings is 4.35 , tableware cleanliness is 4.30 , personnel hygiene practice is 4.25 . The lowest score is washroom cleanliness (4.24). Thus, personnel hygiene practice, tableware cleanliness and washroom cleanliness are the important point for enhance the food safety risk perception.

Table 4 Mean of food safety risk perception for students $(n=148)$

\begin{tabular}{|lccc|}
\hline \multicolumn{1}{|c}{ Variables } & mean & $\begin{array}{c}\text { Standard } \\
\text { deviation }\end{array}$ & $\begin{array}{c}\text { Scoring } \\
\text { ranking }\end{array}$ \\
\hline Cleanliness of surroundings & 4.35 & 0.67 & 2 \\
Washroom cleanliness & 4.24 & 0.83 & 5 \\
Food sanitation & 4.41 & 0.88 & 1 \\
Personnel hygiene practice & 4.25 & 0.76 & 4 \\
Tableware cleanliness & 4.30 & 0.90 & 3 \\
\hline
\end{tabular}

\section{Conclusion}

This study revealed the student's acceptable meal expanse was higher than the real payment of dinning. The purpose of dinning in restaurant was only dinning of students and almost with companies. The meal type, restaurant location and dinning habit were most important factors for more attractive students form vocational school. On the other hand, good foodservice was less attractive for students eat dinning in restaurant. Bad foodservice attitude was caused the dislike most to eat dinning in restaurant. 
We found that the score of personnel hygiene practice, tableware cleanliness and washroom cleanliness for food safety risk perception were the lowest. Thus, enhance food safety risk perception is the important issue. Furth more, our study suggestion that establishing the food safety risk perception and evaluation ability through the food safety course were able to handle the food accident in foodservice industry.

\section{References}

Cenfetelli, R. T. (2004). Inhibitors and enablers as dual factor concepts in technology usage.

Journal of the Association for Information Systems,5(11), 16.

Grunert, K.G. (2002).Current issues in the understanding of consumer food choice, Trends in Food Science \& Technology, 13(8), 275-285.

Haapala, I., \& Probart, C. (2004). Food safety knowledge, perceptions, and behaviors among middle school students. Journal of nutrition education and behavior, 36(2), $71-$ 76.

Lammerding, A. M., \& Fazil, A. (2000). Hazard identification and exposure assessment for microbial food safety risk assessment. International journal of food microbiology, 58(3), 147-157.

Lin, S., \& Sneed, J. (2005). University foodservice employees' food safety knowledge, attitudes, practices, and training. Journal of Foodservice Management and Education, $1(1)$.

Lobb, A.E. (2004). Food risk communication and consumers' trust in the food supply chain. (Working Paper No. 20), Department of Agricultural and Food Economics, University of Reading.

Perlik, A. (2002). Feeding the faith, Restaurants and Institutions, 12(13), 40-48.

Wu, Ming Chang (2015) 。【Food Security Forum】 The crux of food safety problems and its solutions Retrieved from http://www.peoplenews.tw/news/779e3e07-b104-4ad5bb87-5001a09c570d

Yeung, R.M., and Morris, J. (2001). Food safety risk: Consumer perception and purchase behavior, British Food Journal, 103(3), 170-187. 